\title{
Reflexão sobre o impacto dos códigos edilícios no desempenho térmico e lumínico de edifícios residenciais do bairro Noroeste, Brasília-DF
}

Insight about the impact of codes on thermal and lighting performance of residential buildings in Noroeste District, Brasília-DF

Reflexión sobre el impacto de los códigos de edificación en el desempeño térmico y luminoso de edificios residenciales del barrio Noroeste, Brasilia- 


\title{
Resumo
}

As superquadras de Brasília oferecem uma oportunidade ímpar para se examinar em detalhe um determinado tipo arquitetônico: o edifício residencial sobre pilotis, cuja extensiva concentração na cidade permite estudá-lo sob diversas perspectivas. Sob a ótica da Norma de Desempenho NBR15.575(2013), este trabalho evidencia como os códigos edilícios podem impactar as mais recentes construções de projeções residenciais no Setor Noroeste prejudicando o Desempenho Térmico e Lumínico dos apartamentos. Inicialmente, apresenta-se panorama geral resgatando a origem do Plano Piloto e do bairro Noroeste. Em seguida, percorre-se o histórico das normativas de Brasília que incidem diretamente na forma dos edifícios. Apresenta-se, também, uma breve descrição das exigências da Norma de Desempenho. Por fim, a partir da análise morfológica do contexto urbano e das tipologias de edifícios residenciais, demonstra-se como os códigos, somados às demandas do mercado imobiliário, podem limitar a concepção do projeto representando obstáculos para atingir o desempenho mínimo.

Palavras-Chave: Desempenho Térmico e Lumínico; NBR 15.575(2013); códigos edilícios; edifícios residenciais; bairro Noroeste.

\begin{abstract}
Brasilia's superquadras offer a unique opportunity to examine in detail a certain architectural type: the residential buildings with pilotis, whose extensive usage in the city provides the opportunity to study it in several different scenarios. Analyzing the guidelines of the Performance Standard - NBR 15.575(2013), this work makes evident how the building codes can impact the most recent constructions of residential developments in Brasilia's Noroeste District, impairing the thermal and lighting performance of the buildings. Initially, a general panorama is presented, rescuing the origins of the neighborhood. Then, it goes through the history of Brasilia's building codes that directly affect the shape of the constructions. A brief description of the requirements of Performance Standard is also presented. Finally, based on the morphological analysis of the urban context and the typologies of residential buildings, it is demonstrated how the constrain of building codes, added to the demands of the real estate market, can limit the design of the project and represent obstacles to achieve minimum performance.
\end{abstract}

Key-Words: NBR 15.575(2013); thermal and luminous performance; building legislation; residential buildings; Noroeste district.

\section{Resumen}

Las superquadras de Brasilia ofrecen una oportunidad única para examinar en detalle un cierto tipo arquitectónico: los edificios residenciales con pilotis, cuya extensa concentración en la ciudad brinda la oportunidad de estudiarlo en varios escenarios diferentes. Al analizar los lineamientos de la Norma de Desempeño - NBR 15.575 (2013), este trabajo evidencia cómo los códigos de edificación pueden impactar las construcciones más recientes de desarrollos residenciales en el Distrito Noroeste de Brasilia, afectando el desempeño térmico y luminoso de los edificios. Inicialmente se presenta un panorama general, rescatando los orígenes del barrio. Luego, recorre la historia de los códigos de construcción de Brasilia que afectan directamente la forma de las construcciones. También se presenta una breve descripción de los requisitos de la Norma de Desempeño. Finalmente, a partir del análisis morfológico del contexto urbano y de los tipos de edificación residencial, se demuestra cómo la restricción de los códigos de construcción, sumada a las demandas del mercado inmobiliario, limita el diseño del proyecto y representa obstáculos para lograr un desempeño mínimo.

Palabras clave: NBR 15.575 (2013); desempeño térmico y luminoso; legislación de construcción; edificios residenciales; barrio Noroeste. 


\section{Introdução}

Morar sobre pilotis em superquadras é símbolo, é patrimônio, é o código arquitetônico grupal dos brasilienses. Representa a principal maneira de morar dentro do perímetro tombado de Brasília. Não obstante, o bairro Noroeste pode ser visto como a adaptação da superquadra às exigências de um novo século. Aliado à tradição arquitetônica de Lucio Costa de 6 pavimentos sobre pilotis de Brasília, o Noroeste replica, também, exemplos das construções mais recentes de edifícios residenciais do Plano Piloto.

Ao lançar o olhar sobre este modelo de edifícios, em um primeiro momento, pode aparentar soluções e tipologias repetidas, no entanto, tais construções vêm sofrendo alterações desde a inauguração de Brasília. Os blocos mais antigos representam a concepção original perpetuada no documento Relatório do Plano Piloto (Costa, 1957) e, no decorrer das décadas, adaptando-se às circunstâncias de mercado, as lâminas horizontais com empenas de vidro e cobogó foram aos poucos sucedidas por fachadas com avanços e reentrâncias decorrentes das concessões de ocupação de área (Machado, 2007; Fischer et al, 2010).

Conforme a demanda de crescimento da cidade, novos bairros surgiram sob o aval de Lúcio Costa (Costa, 1987), dando continuidade à linguagem de superquadras com prédios sobre pilotis livre, com dimensões e formatos distintos, como é o caso do bairro Noroeste. Importante ressaltar que a legislação de uso e ocupação do solo para os prédios residenciais pouco se alterou. Todavia, foi o surgimento de novos regramentos que permitiu a ocupação de área pública em espaço aéreo e em subsolo, modificando de forma significativa os edifícios construídos atualmente. Isso gerou blocos mais volumosos e, consequentemente, apartamentos mais profundos desafiando o arquiteto a alcançar projetos com melhor desempenho térmico e lumínico.

A preocupação com a melhoria do desempenho térmico e lumínico das edificações perdura com intensidade, abrindo amplos estudos e discussões em diferentes países desde a década de 1970 devido à primeira crise do petróleo (Lamberts et al, 2014). No Brasil, ainda que as discussões sobre desempenho tenham se iniciado nos anos 90, foi após a publicação da NBR 15.575 (2013a), comumente conhecida como "Norma de Desempenho", que se obteve maior enfoque e impacto especialmente na prática de projeto (Sorgato et al, 2014). Para o segmento habitacional do mercado imobiliário brasileiro, a Norma de Desempenho trouxe preocupações com a expectativa de vida útil, o desempenho mínimo e a manutenção dessas edificações.

Diante desse cenário, visando melhor compreensão desta peculiar estrutura urbana e residencial própria da área tombada de Brasília, o presente trabalho objetiva analisar a morfologia do contexto urbano e dos edifícios residenciais do bairro Noroeste sob a ótica do Desempenho Térmico e Lumínico da NBR 15.575 (2013a), partindo da hipótese de haver limitações em função das normas urbanísticas e das exigências do mercado imobiliário para a forma edilícia atingir um desempenho mínimo.

\section{Plano Piloto e a expansão do Setor Habitacional Noroeste}

O plano urbanístico de Brasília de Lucio Costa (1957) foi um marco e é reconhecido e protegido enquanto concepção urbanística do patrimônio moderno pelo Governo do Distrito Federal - GDF - (Decreto $\mathrm{n}^{\circ}$ 10.829/1987), pelo Instituto do Patrimônio Histórico e Artístico Nacional - IPHAN - (Portaria ${ }^{\circ}$ 314/1992) e pela Organização das Nações Unidas para a Educação, a Ciência e a Cultura - UNESCO - em $7 / 12 / 1987$.

A concepção parte do cruzamento de dois elementos morfológicos urbanos estruturais: o Eixo Monumental, que dispõe o centro cívico da administração federal, e o Eixo Rodoviário, levemente arqueado tirando proveito do relevo, tendo ao longo de seu percurso a zona residencial Asa Sul e Asa Norte composta pelas superquadras intercaladas com entrequadras comerciais. 
Dentro de cada quadra existem 11 projeções de 12,5 x 85 metros. O termo "projeção", unidade imobiliária típica de Brasília, diz respeito à área e limites registrados em cartório para as edificações, na qual o pavimento térreo permanece de domínio público. Conforme Fischer et all (2010) e Machado (2007), a projeção constitui um artifício inédito na legislação urbanística brasileira, onde o proprietário deve, obrigatoriamente, ocupar $100 \%$ da projeção apenas acima do térreo, cuja superfície deve permanecer aberta com servidão pública franqueada aos pedestres.

Em 1987, Costa publicou o documento Brasília Revisitada, que serviu de base teórica e argumentativa para as legislações de proteção, citadas anteriormente. No documento, procurou, primeiramente, definir o que é preciso preservar do projeto original da capital moderna e, posteriormente, guiar a expansão da cidade a fim de não a desvirtuar de sua principal função político-administrativa. Quanto à preservação, no âmbito da escala residencial, prevaleceram os edifícios residenciais nos moldes das superquadras, consideradas por Lucio Costa uma nova maneira de viver, própria de Brasília. Enfatizou o gabarito de 6 pavimentos e o térreo livre sobre pilotis, garantindo o solo público e sacramentando a lógica das projeções.

A Figura 01 mostra as áreas de expansão urbana propostas no documento Brasília Revisitada (Costa, 1987). O bairro Noroeste está localizado na área $B$, dentro do perímetro tombado ${ }^{1}$.

Figura 1: Proposta para áreas de expansão urbana do Brasília Revisitada.

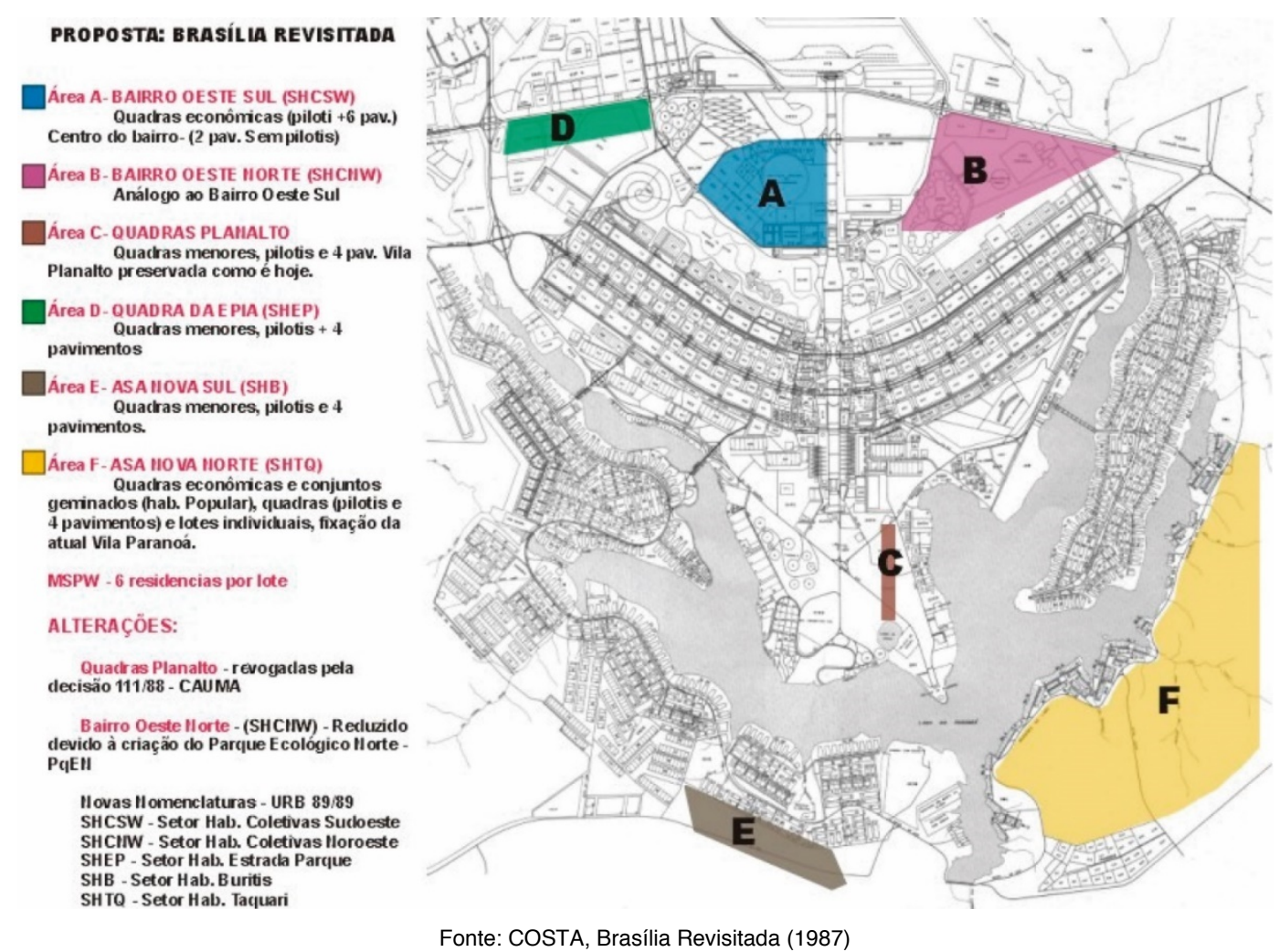

\subsection{O novo bairro - Noroeste}

O novo bairro, atualmente em construção, encontra-se na Zona Urbana do Conjunto Tombado. O projeto urbanístico prevê 20 superquadras, contíguas ao Parque Burle Marx. Sua implantação foi realizada

\footnotetext{
IPHAN, Portaria n³14/1922, Art.1 parágrafo 2: a área abrangida pelo tombamento é delimitada a leste pela orla do Lago Paranoá, a oeste pela Estrada Parque Indústria e Abastecimento - EPIA, ao sul pelo Córrego Vicente Pires e ao norte pelo Córrego Bananal.

${ }^{2}$ Regida pela Norma de Edificação Uso e Gabarito (NGB)-19/09, pelo Memorial Descritivo (MDE)-40/07 e pelo Projeto de Urbanismo (URB)-040/07.
} 
em 2 etapas: a primeira etapa, referente às quadras de final 07 a 11, foi lançada em 2008; e a segunda etapa, referente às quadras de final 02 a 06, em 2013 (Figura 02).

Figura 2: Planta Setor Habitacional Noroeste.

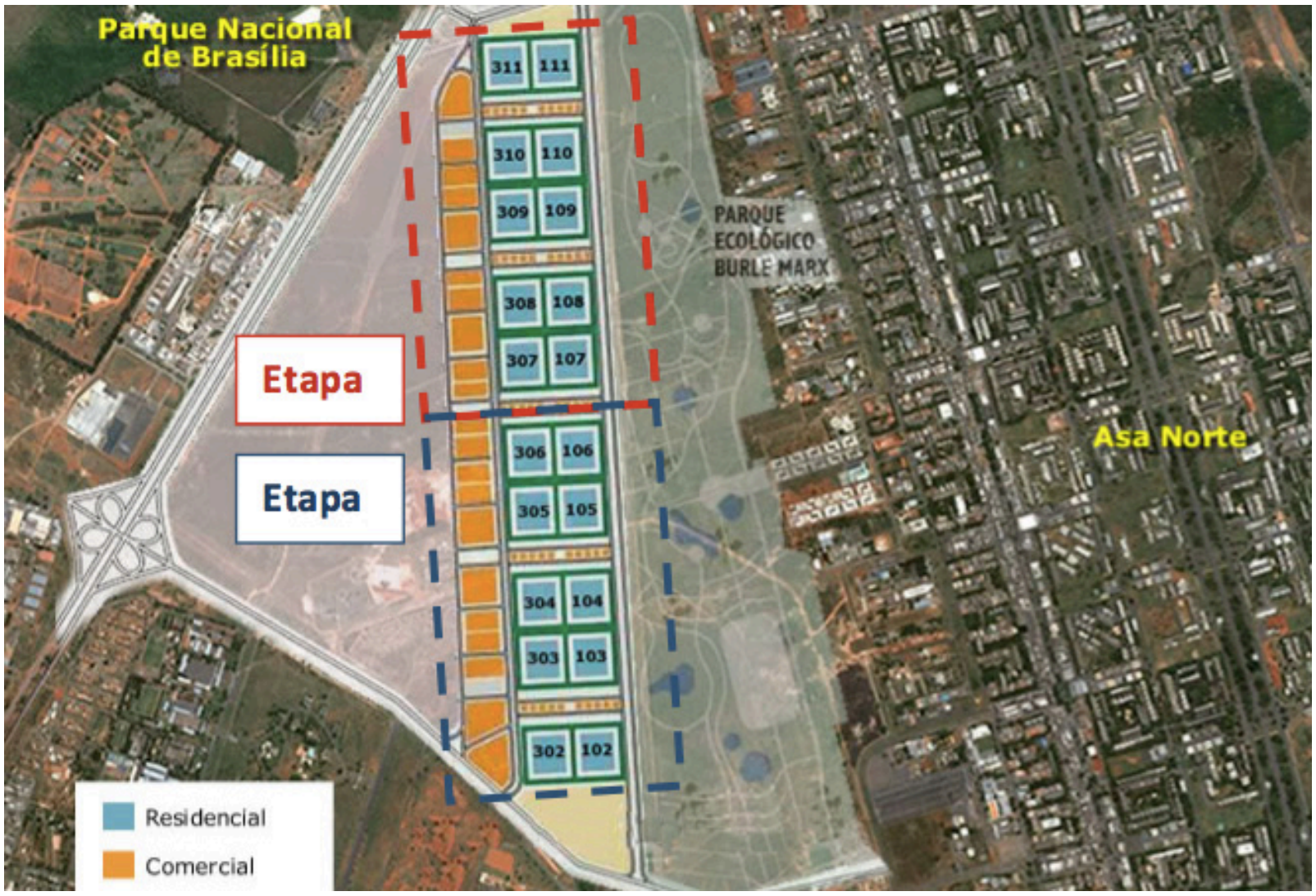

Fonte: Elaborado pela autora

As Superquadras Noroeste (SQNW) estão agrupadas de 4 em 4 intercaladas com Comércio Local Noroeste (CLNW). Assim como nas superquadras da Asa Sul e Norte, dentro de cada superquadra Noroeste existem 11 projeções de 6 pavimentos sobre pilotis, dispostas ordenadamente (Figura 3 e 4).

Figura 3: Croqui do agrupamento de 4 Superquadras Noroeste com comércio local e regional.

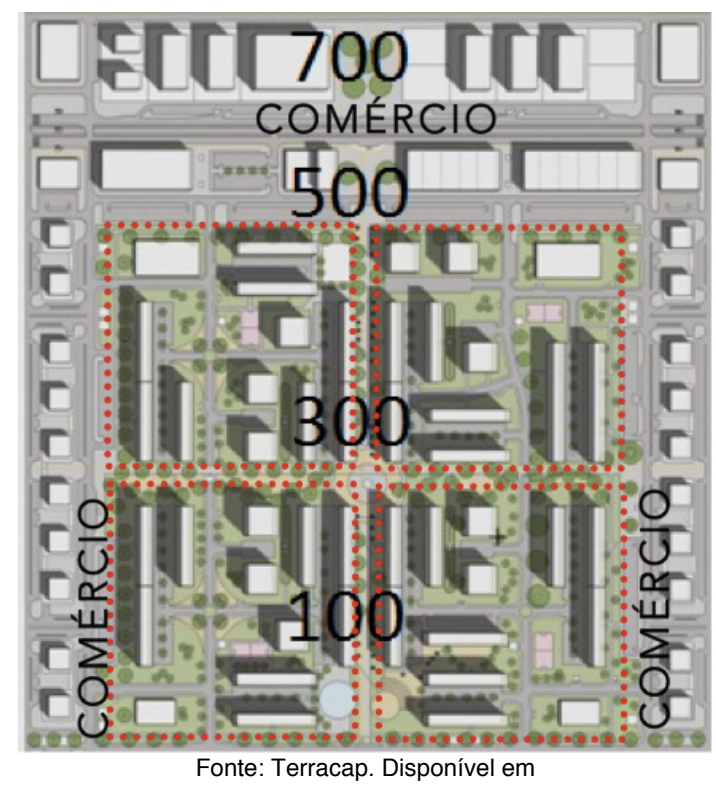

Fonte: Terracap. Disponivel em
https://www.terracap.df.gov.br/setor-noroeste. Acesso, junho 2020
Figura 4: Imagem aérea de satélite das 4 Superquadras Noroeste com comércio local e regional.

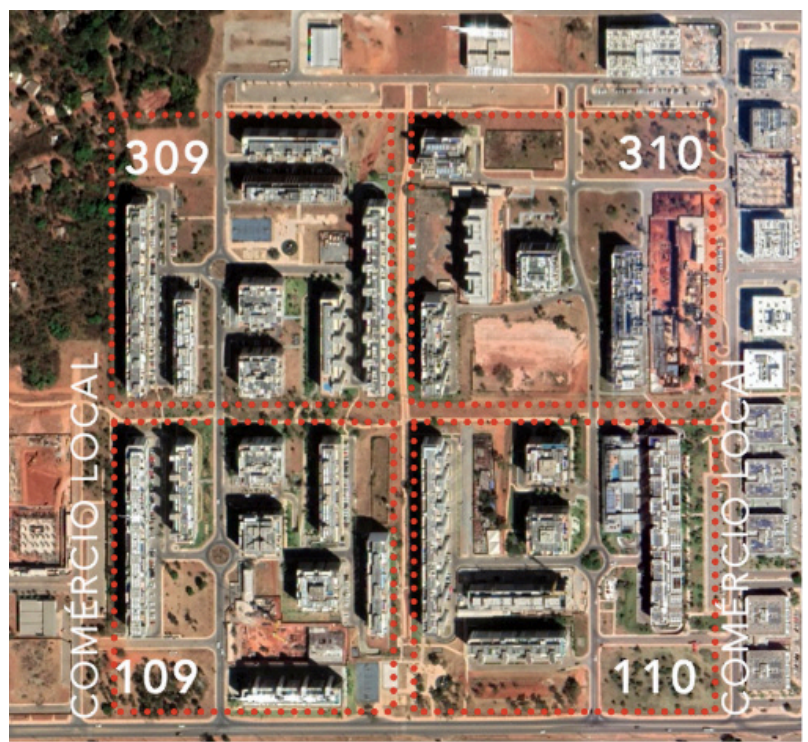

Fonte: Google Earth. Image 23/09/2019 
Existem 2 formatos de projeções, as retangulares e as quadradas. As projeções retangulares da etapa $1^{2}$ possuem $12,5 \times 80$ metros $\left(1.000,0 \mathrm{~m}^{2}\right)$, e as quadradas $32 \times 32$ metros $\left(1.024,0 \mathrm{~m}^{2}\right)$. Já na etapa $2^{3}$, as projeções diminuíram o tamanho sem nenhuma justificativa expressa nos memoriais, sendo as retangulares registradas com $11,5 \times 80$ metros e as quadradas com $30 \times 30$ metros.

Em termos de implantação, a distância entre os blocos aumentou. Com o acréscimo de 8,0 metros, totalizando distância de 28,0 metros entre as projeções, foi possível dispor de calçadas acessíveis e de jardins entre as vagas de veículos e o pilotis, além de prever canteiro central ajardinado. Apesar disso, é discutível afirmar que houve melhoria na iluminação e ventilação para os apartamentos com aberturas voltadas para o bolsão de estacionamento, uma vez que a proporção do cânion urbano ${ }^{4}$ aumentou proporcionalmente.

Enquanto nos blocos originais, a distância entre blocos é de 20,0 metros e altura de 23,0 metros, resultando na proporção de $1: 1,15$, nos blocos do Noroeste, considerando os avanços aéreos do pavimento tipo, obtemos a distância entre blocos de 24,0 metros e altura de 28,0 metros, ou seja, praticamente a mesma proporção observada entre blocos originais.

A Figura 5 ilustra o comparativo entre o distanciamento, a altura e a largura dos edifícios. Demonstra o aumento de $32 \%$ da largura dos edifícios da etapa 1 em relação a largura da projeção original proposta por Costa. Já nos edifícios da etapa 2, há incremento de 24\%.

Figura 5: Comparativo das seções esquemáticas transversais das projeções residenciais do Noroeste e das projeções originais das Asas Norte e Sul.

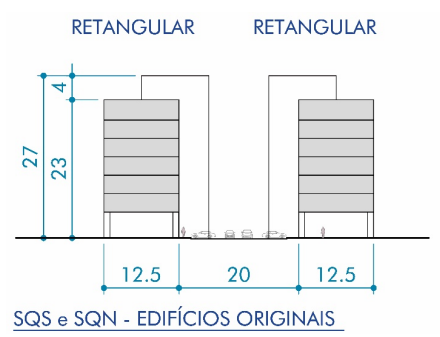

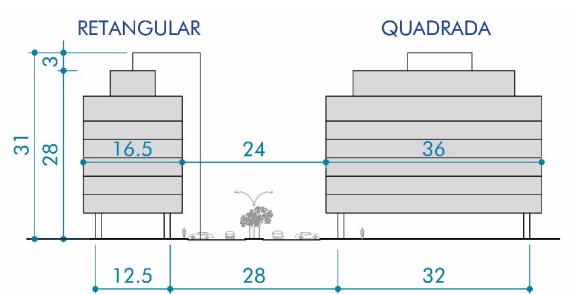

SQNW - EDIFÍCIOS ETAPA 1

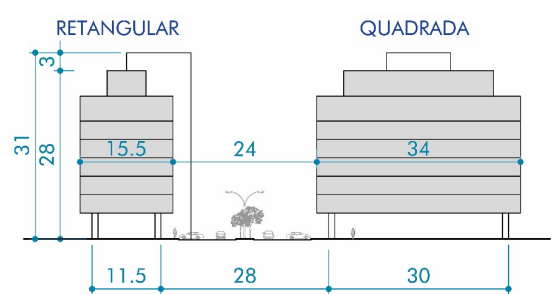

SQNW - EDIFÍCIOS ETAPA 2

Fonte: Elaborado pela autora

Grosso modo, as Superquadras Noroeste não têm previsão de edifícios de apartamentos de um quarto ou de quitinetes, com exceção de algumas projeções cujos projetos foram aprovados antes de $2010^{5}$. A tipologia de um quarto é permitida apenas nas projeções quadradas de $30 \times 30$ metros de uso misto do comércio local, CLNW (Figuras 2, 3 e 4).

Esta tipologia tem recuo de 4 metros no pavimento térreo, formando as galerias de lojas, cujo gabarito de 11,5 metros possibilita térreo, sobreloja e mais 2 pavimentos (Figura 6). No $1^{\circ}$ e $2^{\circ}$ pavimento, são permitidos apartamentos de um e dois quartos, de forma a atender a demanda por este tipo de moradia, não contemplada nas superquadras residenciais.

Figura 6: Seção esquemática transversal da projeção mista do Comércio Local Noroeste.

\footnotetext{
${ }^{2}$ Regida pela Norma de Edificação Uso e Gabarito (NGB)-19/09, pelo Memorial Descritivo (MDE)-40/07 e pelo Projeto de Urbanismo (URB)-040/07.

${ }^{3}$ Regida pelas NGB-115/10, MDE 031/08 e URB031/08.

${ }^{4}$ Termo utilizado na morfologia urbana que representa a relação entre a altura das edificações e a largura de via (Silva, 2013).

${ }^{5}$ Após o Decreto $n^{\circ} 32.434 / 2010$, são permitidos apenas apartamentos de 2 ou mais quartos nos blocos de 6 pavimentos.
} 


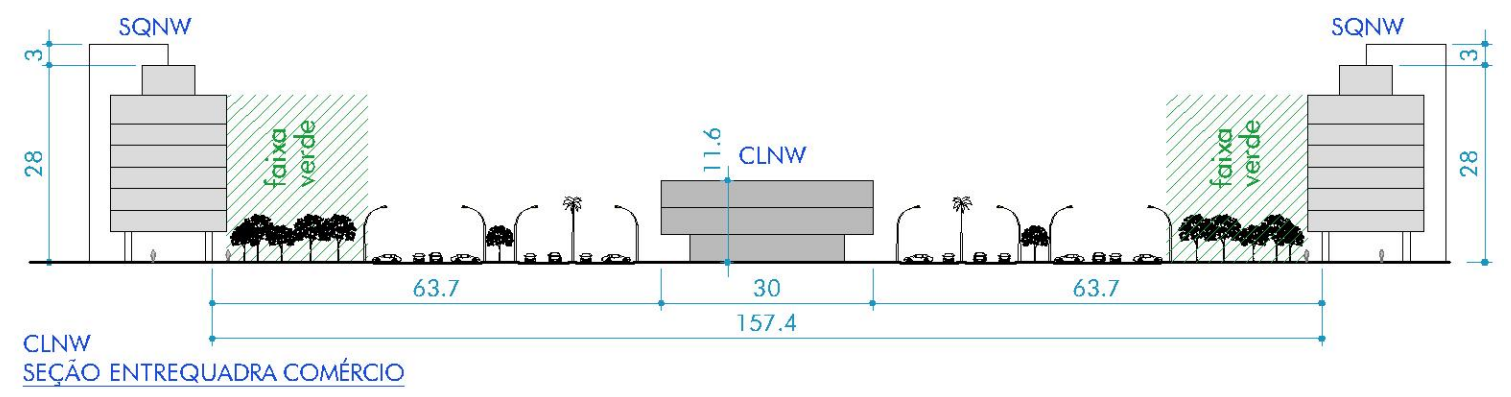

Fonte: Elaborado pela autora

\subsection{Método}

O método consiste em análise morfológica do contexto urbano e dos edifícios residenciais do bairro Noroeste e consequente efeito desta morfologia no Desempenho Térmico e Lumínico (NBR 15.575/2013a) das unidades habitacionais ali localizadas.

Visando melhor compreensão desta peculiar morfologia urbana e residencial própria da área tombada de Brasília, introduz-se o trabalho com a evolução cronológica da legislação urbanística e edilícia do Plano Piloto de Brasília, da qual se origina a legislação do Bairro Noroeste. A análise avança no sentido de levantar pontos específicos das leis que permitiram as transformações morfológicas, já citadas, dos blocos originais para o que está em construção atualmente, a fim de melhor embasar as análises de Desempenho Térmico e Lumínico das tipologias de prédios residenciais no bairro Noroeste.

Em seguida, a partir da experiência das duas autoras deste artigo com projeto de arquitetura e avaliação de Desempenho Térmico e Lumínico dos edifícios residenciais do bairro Noroeste, e com base nos relatórios de Kos (2014 a 2020) e de Nicoletti (2014 a 2020), é realizado um levantamento das principais dificuldades encontradas nas tipologias residenciais para atendimento a NBR 15.575 (2013a) em função dos limitantes das normas urbanísticas.

\section{Legislação urbanística e edilícia dos edifícios residenciais do bairro Noroes- te}

Embora seja lembrada como uma cidade planejada, Brasília, aqui entendida como a Zona do Conjunto Urbanístico Tombado, ainda não dispõe de um Plano Diretor ${ }^{6}$, documento obrigatório pela Constituição de 1988 e regulamentado pelo Estatuto da Cidade ${ }^{7}$.

Atualmente, de um modo geral, as edificações do Plano Piloto são regidas pelo Código de Obras, pelas respectivas URBs (Projeto de Urbanismo) e NGBs (Normas de Edificação, Uso e Gabarito), que fazem o papel da Lei de Uso e Ocupação do Solo definindo índices, taxas e demais parâmetros urbanísticos para cada setor ou lote específico. E, também, por um adendo de diversas leis específicas que discorrem, por exemplo, sobre ocupação de área pública, permeabilidade e quantidade de vagas.

No caso das projeções residenciais do Setor Noroeste, incidem os regramentos locais: a Lei do Código de Obras ${ }^{8}$;

(ii) a lei sobre ocupação de área pública mediante concessão de direito real de uso ${ }^{9}$; e

\footnotetext{
${ }^{6}$ Está em fase final de revisão para conseguinte aprovação na Câmara Legislativa do Distrito Federal a minuta do Plano de Preservação do Conjunto Urbanístico de Brasília (PPCUB), que pode ser compreendido como o Plano Diretor da área tombada. Trata-se de uma Lei Complementar que irá compilar e consolidar toda a legislação urbanística, patrimonial e edilícia pertinente à área tombada, para guiar de forma coesa o crescimento e a preservação. ${ }^{7}$ Brasil. Lei $n^{\circ} 10.257 / 2001$, que regulamenta os arts. 182 e 183 da Constituição Federal, estabelece diretrizes gerais da política urbana e dá outras providências.

${ }^{8}$ DF, Lei $n^{\circ} 6.138 / 2018$ e regulamentada pelo Decreto $n^{\circ} 39.272 / 2018$.

${ }^{9}$ DF, Lei Complementar $n^{\circ} 755 / 2008$ e regulamentada pelo Decreto $n^{\circ} 29.590 / 2008$.
} 
(iii) as normas específicas para o bairro Noroeste, que são as NGBs 019/09 (Etapa 1) e 115/10 (Etapa 2).

Diante do escopo deste estudo, a análise se aprofundará nos regramentos que influenciam as mudanças do pavimento tipo dos projetos arquitetônicos dos prédios residenciais recém construídos no Noroeste e que, de algum modo, impactam nos níveis de Desempenho Térmico e Lumínico.

\subsection{Volume da torre}

A morfologia dos edifícios conta a história de sucessivos aumentos de área em função da evolução da concessão de área pública em espaço aéreo e solo. A Figura 7 ilustra a evolução dos mecanismos introduzidos pelos diferentes regramentos legais que permitiram o aumento do volume da torre. Para fim de comparação, foi utilizada como exemplo uma projeção com as dimensões da etapa 1 do Noroeste.

Figura 7: Evolução das mudanças no pavimento tipo em função do avanço em espaço aéreo.

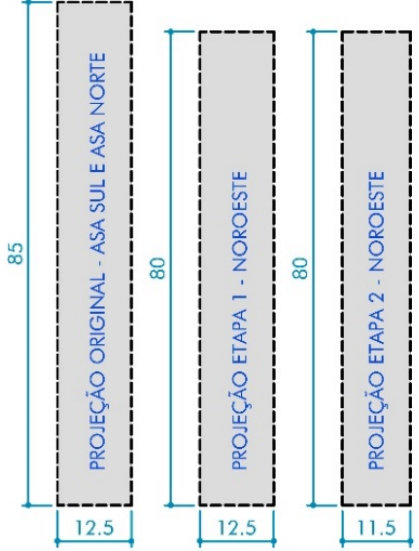

ESQUEMA A

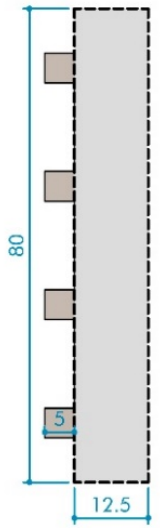

ESQUEMA B

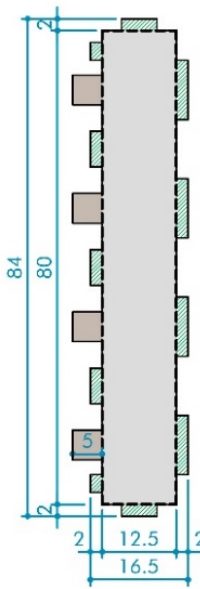

ESQUEMA C

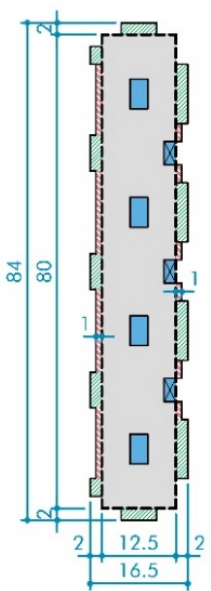

ESQUEMA D

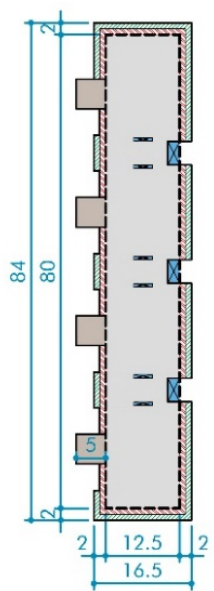

ESQUEMAE

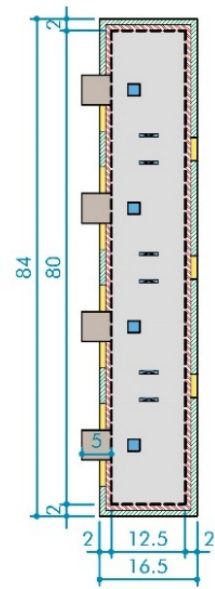

ESQUEMAF
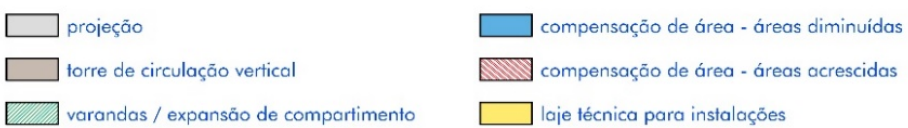

Fonte: Fischer et al (2009, p.264 e 265) e Braga (2005, p.15) com adaptações da autora

Nos primórdios, décadas de 1960 e 1970, o bloco original tinha a projeção típica de 12,5 x 85 metros, não diferindo tanto das atuais projeções do Noroeste de $12,5 \times 80$ metros ou $11,5 \times 80$ metros, respectivamente etapas 1 e 2 (Figura 7, esquema A). Em 1967, permitiu-se a ocupação de área pública com as torres de circulação vertical, que podem avançar 5 metros em relação ao limite da projeção (Figura 7, esquema B). Em 1975, foi permitido avanço de 2 metros em balanço, além do limite da projeção, para as varandas. Estas não seriam computadas na área máxima de construção, latente demanda do mercado imobiliário, com aumento de área privativa de venda sem interferir no índice urbanístico (Figura 7 , esquema C).

Já em 1989, o Código de Edificação estendeu a utilidade do avanço do espaço aéreo para "compensação de área", onde as áreas de reentrâncias e vazios acima do térreo poderiam ser compensadas em seu perímetro com balanço de até 1 metro, mantendo a equivalência de área máxima ocupada do pavimento. Em outras palavras, diferentemente das varandas, os avanços de compensação são computados na área máxima de construção e podem ser utilizados para compensar área mínima de qualquer cômodo do apartamento para fora da projeção. Ainda nesse código, foi autorizado, quando a torre de circulação vertical estivesse dentro da projeção, compensar a totalidade da sua área para fora (Figura 7, esquema D). Em consequência, esse aumento da largura do pavimento tipo possibilitou partidos arquitetônicos com apartamentos longitudinais não vazados (Machado, 2007; Fischer et al, 2009; Bra- 
ga, 2005).

Usualmente, as varandas eram fechadas pelos usuários com esquadrias de vidro a fim de aumentar as áreas dos cômodos lindeiros. Assim, em 1998, o Código de Obras e Edificações ${ }^{10}$ legalizou os fechamentos de varanda intitulando-os como expansão de compartimento, que poderiam ser utilizados apenas nos cômodos de permanência prolongada, como quartos e salas (Figura 7, esquema E).

Posteriormente, todas as autorizações de avanços para fora da projeção no espaço aéreo foram compiladas em lei específica sobre ocupação de área pública mediante concessão de direito real de uso, atualmente, a Lei Complementar (LC) n`755 de 2008, regulamentada pelo Decreto n`29.590 de 2008.

Em relação ao volume da torre, a $L C n^{\circ} 755 / 2008$ referenda praticamente todos os avanços já citados e acrescenta pontos inéditos que são claramente observados nos blocos do Noroeste. Dentre as mudanças, destaca-se a possibilidade de continuidade entre as varandas e as expansões de compartimento por meio de interligação em todo o perímetro da edificação. E, por fim, a possibilidade de ocupação em espaço aéreo com instalações técnicas, comumente denominadas de lajes técnicas de arcondicionado.

Desse modo, como as expansões de compartimentos e as varandas já garantiam o avanço máximo de 2 metros e só poderiam ocorrer em salas e quartos, e os banheiros e as cozinhas só podem avançar 1 metro como compensação de área, nesta diferença de 1 metro que "sobraria" na frente das áreas moIhadas, locaram-se as lajes técnicas na grande maioria dos novos empreendimentos. Assim os blocos residenciais do Noroeste ocupam todo o perímetro da projeção com o avanço máximo de 2 metros permitido (Figura 7, esquema F).

Após a introdução de tantas variações legais, é possível compreender como a projeção de $12,5 \times 80$ metros do Noroeste resulta em um perímetro de 16,5 × 84 metros, aumento de $38,6 \%$ de área do pavimento tipo. Assim, a principal alteração introduzida pelas leis refere-se ao aumento da área construída por pavimento e o consequente aumento da massa edificada por superquadra. Depreende-se, então, possível piora no Desempenho Térmico e Lumínico, uma vez que ora o apartamento será muito profundo e com pouca fachada, ora será longitudinal não vazado sem ventilação cruzada recebendo luz natural apenas de um lado.

\subsection{Fachadas}

Quanto à ordenação do partido plástico, os blocos residenciais construídos nas décadas de 1950 e 1960, cuja morfologia caracteriza a linguagem arquitetônica do período de implantação de Brasília, em geral, têm feição de lâminas horizontais onde predominam componentes retilíneos e ortogonais. A fachada frontal consiste usualmente de vidro com faixas contínuas de esquadrias e elementos de proteção solar fixos. Já a fachada posterior, onde normalmente são dispostas as cozinhas e áreas de serviço, tem a presença quase unânime dos cobogós ${ }^{11}$, obrigatoriedade do código de 1960 (Machado, 2007; Fischer et al, 2009).

Ao longo do tempo, a partir da consolidação das normas e com os acréscimos de áreas no pavimento tipo, os edifícios retilíneos foram desaparecendo, dando lugar a fachadas diversificadas com recortes dos avanços das varandas e das compensações. Em 1998, conforme já exposto, o Código de Obras legalizou o fechamento das varandas para expansão de quartos e salas, por meio de material que permita a permeabilidade ou transparência visual, instalado sobre o guarda-corpo.

Desde a autorização dos fechamentos, os regramentos citam a necessidade de transparência visual

\footnotetext{
${ }^{10} \mathrm{DF}$, Lei $\mathrm{n}^{\circ}$ 2.105/1998 e regulamentada pelo Decreto $\mathrm{n}^{\circ}$ 19.915/1998

"Cobogós são elementos vazados de cimento ou argamassa, empregados para iluminação e ventilação natural e permanente.
} 
acima do peitoril nas expansões de compartimentos e varandas. Contudo, foi apenas em 2012, que essa transparência se tornou compulsória, com a publicação do Parecer Técnico nº01/2012 da Coordenadoria das Cidades. Conforme essa decisão, firmou-se o entendimento de a expansão não ter origem autônoma, mas, sim, origina-se a partir do fechamento da varanda, o que somente é possível com utilização de material com transparência visual instalado sobre guarda-corpo. Assim, passou a ser imperativo o uso predominante de vidro nas fachadas para os partidos de projetos que façam uso dos 2 metros de avanço.

A NGB19/09 (1 $1^{\text {a }}$ Etapa do Setor Noroeste), quanto à fachada, determina que molduras, brises e jardineiras são permitidos, porém não devem ultrapassar o avanço de 2,00 metros permitido em área pública. Já em 2013, a NGB115/10 (2 $2^{\text {a }}$ Etapa do Setor Noroeste), traz como novidade item sobre a proibição de revestimentos e vedações espelhados nos edifícios lindeiros às unidades de conservação, no entanto, não fixa parâmetros mínimos.

Desse modo, em decorrência da mecânica de consolidação das diversas normas e das diferentes interpretações dadas ao longo do tempo para soluções já em uso, é comum alguns edifícios apresentarem fachadas com características distintas com a mesma legislação em vigor. As Figuras 8 e 9 ilustram 2 blocos residenciais do Noroeste aprovados em anos distintos sob os parâmetros da mesma legislação.

Figura 8: Via Ibiza, construtora Via Engenharia. Projeto aprovado em 2008.

Figura 9: Jardim dos Ipês, construtora Emplavi. Projeto aprovado em 2016.

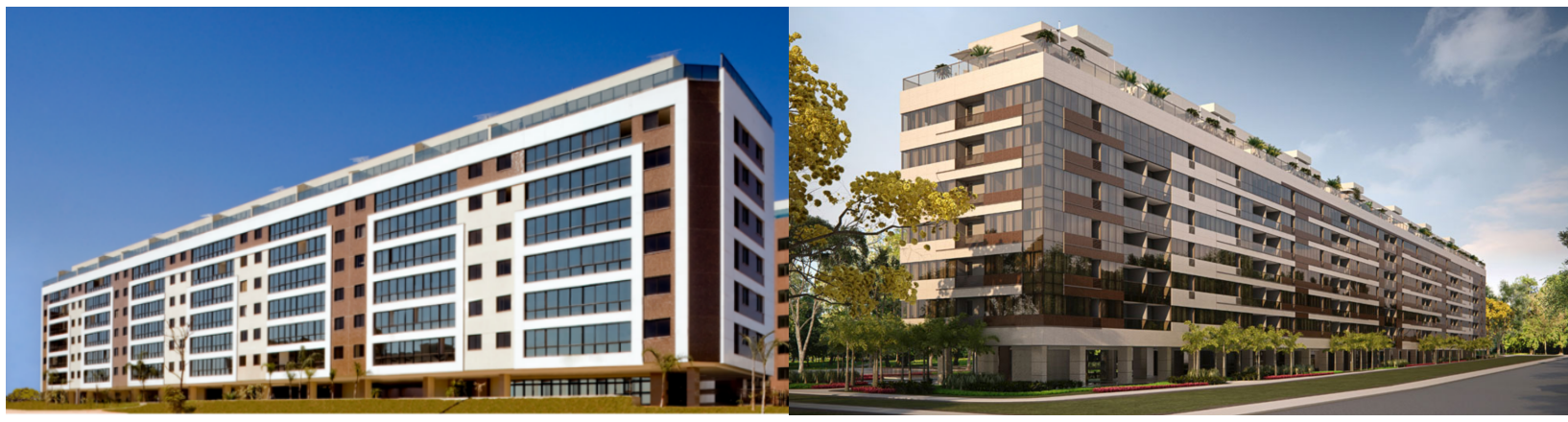

Fonte: Edgar César. Disponível em

Fonte: Google Earth. Image 23/09/2019

https://www.edgardcesar.com/corporativo-1, acesso junho 2020

Uma das construções pioneiras foi o Via Ibiza (Figura 8), aprovado no mesmo ano de lançamento da etapa 1 do bairro, onde é possível observar os fechamentos opacos acima da altura do peitoril no avanço de 2 metros. Já o Jardim dos Ipês (Figura 9), aprovado em 2016, possui forte linguagem de faixas horizontais com praticamente nenhum fechamento opaco acima do peitoril, e representa a etapa 2 do Setor Noroeste, pós Norma de Desempenho. Nesse momento, a exigência de fechamento com transparência visual sobre peitoril já está pacificada. Em ambos os casos, é possível observar os pilares recuados no pilotis, demonstrando o tamanho real da projeção e a utilização do avanço aéreo de 2 metros em todo o perímetro da torre.

Os limitantes presentes nas normas urbanísticas e edilícias do Noroeste, somados à demanda do mercado imobiliário por mais área privativa vendável, têm influenciado a concepção do projeto arquitetônico e a definição da tipologia da unidade habitacional. Conforme exposto, esse contexto engessa a forma e a composição plástica da envoltória, e provoca estreitamento dos cômodos.

\section{Desempenho Térmico e Lumínico}

Para além das leis locais, todas as edificações habitacionais aprovadas após 19 de julho de 2013 devem obrigatoriamente atender à Norma Brasileira 15.575 (ABNT, 2013a), comumente conhecida como Norma de Desempenho. Essa norma busca avaliar se a edificação cumpre sua função de forma satis- 
fatória a partir das exigências dos usuários, independente dos materiais constituintes ou do sistema construtivo utilizado. Para tanto, determina parâmetros mínimos obrigatórios para os principais sistemas que compõem o edifício, conforme a zona bioclimática em que se insere. Quanto à habitabilidade, a norma prevê três níveis de desempenho, sendo o desempenho mínimo expresso em função das necessidades básicas. Já os níveis intermediários e superior consideram a possibilidade de agregar maior qualidade à edificação.

O Desempenho Térmico pode ser avaliado por dois métodos: método Simplificado e método por Simulação Computacional. A avaliação pelo método Simplificado é realizada apenas com base nas propriedades térmicas das paredes externas e coberturas, ou seja, de fechamentos opacos. Dessa forma, para os edifícios do Setor Noroeste, que têm área significativa de fechamentos transparentes, a avaliação apenas pelo método simplificado tem-se mostrada insuficiente. A simulação computacional permite que a área envidraçada seja incluída nas análises, atestando sua real influência (Kos, 2020; Sorgato et al, 2014).

No método da Simulação Computacional, a avaliação é separada em situações de dia típico de verão e de inverno, onde compara-se a diferença entre as temperaturas do ar interno e externo. Para o verão, o desempenho mínimo é atingido, quando, em todos os ambientes de permanência prolongada, a temperatura máxima interna seja menor ou igual a temperatura máxima externa. Já para as avaliações no inverno, o desempenho mínimo é atingido quando a temperatura mínima interna é maior ou igual a temperatura mínima externa acrescida de $3^{\circ} \mathrm{C}$.

No caso de Brasília, no dia típico de verão, o ambiente atende ao desempenho mínimo se atingir até $31,2^{\circ} \mathrm{C}$; já o desempenho mínimo no dia típico de inverno é alcançado a partir de $13^{\circ} \mathrm{C}$. (Tabela 1 ).

Tabela 1: Dados de dias típicos de verão e inverno de Brasília.

\begin{tabular}{lc|lc}
\hline \multicolumn{2}{c|}{ Dia típico de verão } & \multicolumn{2}{c}{ Dia típico de inverno } \\
\hline Temperatura máxima diária & $31,2^{\circ} \mathrm{C}$ & Temperatura mínima diária & $10^{\circ} \mathrm{C}$ \\
Amplitude diária de temperatura & $12,5^{\circ} \mathrm{C}$ & Amplitude diária de temperatura & $12,2^{\circ} \mathrm{C}$ \\
Temperatura de bulbo úmido & $20,9^{\circ} \mathrm{C}$ & Temperatura de bulbo úmido & $14,8^{\circ} \mathrm{C}$ \\
Radiação Solar & $4625 \mathrm{Wh} / \mathrm{m}^{2}$ & Radiação Solar & $4246 \mathrm{Wh} / \mathrm{m}^{2}$ \\
Nebulosidade & 4 décimos & Nebulosidade & 3 décimos \\
\hline
\end{tabular}

Fonte: Tabelas A2 e A3 do Anexo A, NBR 15.575-1 (2013)

Quanto ao Desempenho Lumínico, deve-se analisar a sala, o quarto, a copa/cozinha e a área de serviço. Para atender ao nível mínimo, esses cômodos devem apresentar a iluminância de no mínimo 60 lux, no centro de cada ambiente, contando unicamente com iluminação natural. As simulações devem ser realizadas nos dias 23 de abril e 23 de outubro às 9:30 e às 15:30, com céu parcialmente nublado (50\% de nuvens). A fim de garantir maior conforto dos usuários, a NBR 15575 recomenda atendimento aos níveis intermediário e superior, cuja iluminância mínima é de 90 lux e de 120 lux, respectivamente, no centro do ambiente. Banheiros, corredores, escadarias, garagens e estacionamentos não possuem exigência para atendimento.

Em edifícios residenciais, devem ser analisadas as diferentes tipologias de apartamentos, em diferentes orientações. Devem ser escolhidas as unidades com condições menos favoráveis de iluminação natural, nos pavimentos mais baixos e com entorno mais obstruído.

\subsection{Desempenho térmico em edifícios residenciais do bairro Noroeste}

Para avaliação de Desempenho Térmico pelo método da Simulação, devem ser simuladas as unidades mais críticas, do ponto de vista térmico. No verão, a unidade habitacional do último pavimento com aberturas voltadas para norte e oeste são as que recebem maior carga térmica. No inverno, as unida- 
des críticas são as da cobertura, voltadas para sul e leste. No caso do bairro Noroeste, todos os edifícios apresentam as fachadas norte e oeste com azimutes de $355^{\circ}$ e $265^{\circ}$, respectivamente. Já no caso das fachadas sul e leste, os azimutes são de $175^{\circ}$ e $85^{\circ}$, respectivamente.

As inúmeras análises de Desempenho Térmico dos edifícios residenciais no bairro Noroeste $^{12}$ têm evidenciado que não há dificuldades no atendimento dos parâmetros no dia típico de inverno. De um modo geral, o atendimento se deu nos níveis superior ou intermediário, sem qualquer necessidade de intervenção no projeto de arquitetura. Desse modo, o artigo focará nos desdobramentos para as avaliações de verão, onde surgem os maiores obstáculos.

Independente do modelo de projeção residencial, seja quadrada ou retangular, via de regra, no verão, o ambiente crítico é o situado no canto norte-oeste, normalmente uma suíte ou uma sala de estar. Como se localiza no avanço de 2 metros além da projeção, é compulsório o fechamento com transparência visual sobre peitoril neste ambiente, assim, obrigatoriamente, possui janela corrida nas 2 paredes externas (Figura 9). Nessa situação, em uma suíte típica com área de $15 \mathrm{~m}^{2}$, peitoril opaco e pé-direito com altura de 2,5 metros, a área envidraçada ultrapassa facilmente $70 \%$ da área do piso $^{13}$. Nestes cômodos, é comum as simulações térmicas acusarem temperaturas máximas acima de $35^{\circ} \mathrm{C}$.

O resultado depende, além do tamanho da área envidraçada, do tipo de vidro, da composição dos fechamentos opacos, principalmente da cobertura, e da geometria do ambiente. $O$ atendimento ao nível mínimo, na maioria dos casos, só é possível com especificação de vidros de controle solar, com fator solar abaixo de $40 \%$. Ainda assim, observa-se casos que, embora se utilize o vidro de melhor performance, o desempenho mínimo só é alcançado com a aplicação das estratégias adicionais de ventilação natural e de sombreamento das aberturas. ${ }^{14}$

Mesmo com o latente ganho térmico que o vidro proporciona para o dia típico de verão, são comuns os projetos que propõem vidro até mesmo no peitoril dos ambientes críticos, privilegiando-se o conceito estético da fachada, como exemplificam as Figuras 10 e 11.

Figura 10: Edifício Reserva Biografia, construtora Brasal.

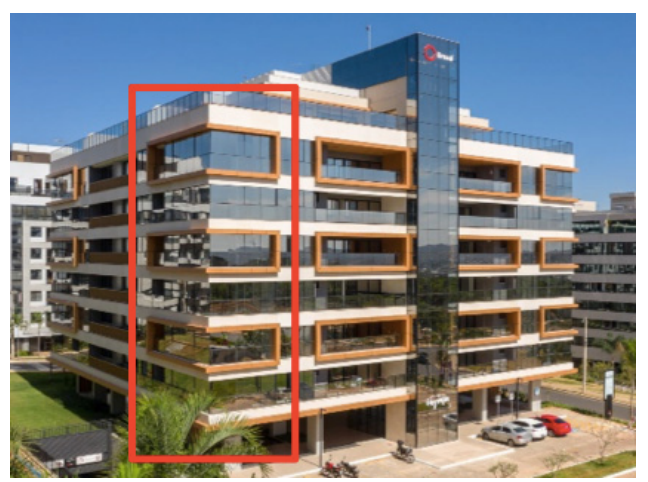

Fonte: Brasal. https://www.brasal.com.br, acesso março 2021
Figura 11: Edifício Vivant, construtora Villela e Carvalho.

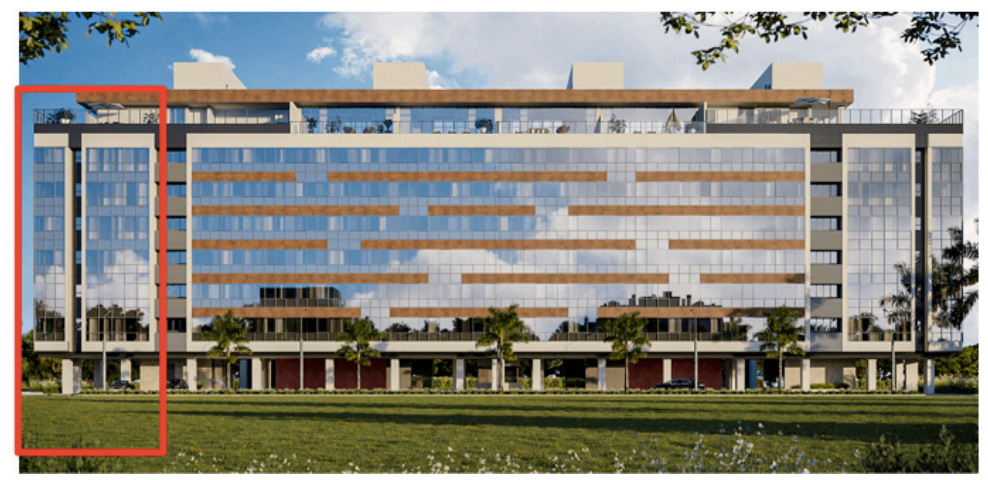

Fonte: Villela e Carvalho. Disponível em https://www.construtoravillela.com.br, acesso março 2021

Neste caso, o subterfúgio para atendimento do desempenho mínimo é o sombreamento externo ou interno, que bloqueia, no mínimo, $50 \%$ da radiação direta. $O$ artifício mais usual em projeto é a especi-

\footnotetext{
${ }^{12}$ Nicoletti, 2014 a 2020.

${ }^{13}$ Para efeito de comparação, o Código de Obras, Lei n6.138/2018, fixa a dimensão mínima para vãos de iluminação e ventilação de salas, quartos e cozinhas em 1/8 da área do piso, ou seja, $12,5 \%$.

${ }^{14}$ Quando o desempenho mínimo no dia típico de verão não é alcançado, a norma permite ainda uso de estratégias adicionais. A primeira é considerar a taxa de ventilação de 5 renovações de ar por hora, configurando as janelas abertas. A segunda é o sombreamento externo ou interno, que bloqueia, no mínimo, $50 \%$ da radiação direta. A terceira é a combinação das duas estratégias anteriores.
} 
ficação de um peitoril opaco interno, com características de transmitância térmica e capacidade térmica que permitam atendimento por simulação. Em alguns casos, utilizar pontualmente a estratégia de sombreamento, ainda não garante o desempenho térmico mínimo. A depender da orientação solar e da geometria do ambiente, é necessário combinar o aumento da taxa de ventilação e o sombreamento interno para alcançar a temperatura de $31,2^{\circ} \mathrm{C}$.

Outro caminho, bem mais oneroso, é a especificação de vidros duplos com fator solar baixo, isolamento muito eficiente de cobertura e uso de proteções solares externas ou internas (cortinas e persianas), cuja utilização e manutenção dependem do usuário.

No que se refere às proteções solares externas, as NGB-19/09 e NGB-115/10 autorizam o uso destes elementos, porém proíbem ultrapassar o avanço de 2,00 metros, logo, é necessário recuar a fachada e perder área privativa de venda para utilizá-los. Dessa forma, são poucos os partidos de projeto no Noroeste que utilizam brises ou beirais que avançam para além da janela. Outra solução positiva de sombreamento externo é o uso de varanda nos cantos da projeção. No entanto, no bairro Noroeste, também são pouquíssimos empreendimentos que adotam esta estratégia. Já a ventilação e o controle de dispositivos de sombreamento internos são diretamente ligados ao comportamento do usuário. Tais medidas são paliativas e demonstram que o desempenho mínimo assegurado pela norma não é garantido pela edificação, mas pela ação do usuário (Nicoletti, 2014 a 2020).

Por fim, a maioria das construtoras atuantes no Setor Noroeste também acumulam a função de incorporadora $^{15}$, e já tem o padrão de acabamento do empreendimento pré-definido. A especificação, particularmente para revestimentos de fachada, é feita pelas equipes de suprimentos das incorporadoras, normalmente mais preocupadas com custo do material e o apelo estético. A partir da publicação da NBR 15.575, tornou-se obrigatório a melhoria do desempenho da construção, mesmo que mínimo. Assim, como no Noroeste, ao menos $50 \%$ da fachada é, impreterivelmente, com vedação transparente, ao menos se tornou obrigatório para a equipe de suprimentos a melhoria com a qualidade dos vidros de controle solar, a fim de minimizar os ganhos térmicos pelas áreas envidraçadas.

Contudo, cabe esclarecer que desempenho e conforto não andam necessariamente juntos. Embora o cômodo atenda ao desempenho mínimo, não significa que o ambiente trará conforto térmico ao usuário (Lamberts et al, 2014). Os estudos de bioclimatologia de Givoni verificam que a sensação de conforto térmico para os habitantes de países tropicais pode ser obtida entre temperaturas de $18{ }^{\circ} \mathrm{C}$ e $29^{\circ} \mathrm{C} \mathrm{e}$ umidade relativa variando de $20 \%$ a $80 \%$ (Lamberts et al, 2016). Portanto, quando o edifício não proporciona conforto em seu interior, o usuário buscará condicionamento artificial, impactando diretamente o consumo energético. Todos os edifícios residenciais do Noroestes preveem pelo menos uma laje técnica por unidades habitacional, visando à instalação das unidades externas do sistema Split de arcondicionado cuja utilização e manutenção dependem do usuário.

Diante do exposto, o histórico de relação entre alta taxa de envidraçamento em detrimento das faces opacas nos avanços em espaço aéreo traz a raiz da questão do Desempenho Térmico para o Setor Noroeste.

\subsection{Desempenho lumínico em edifícios residenciais do bairro Noroeste}

Os edifícios residenciais do bairro Noroeste apresentam unidades habitacionais a partir do primeiro pavimento, não há unidades no térreo. Para as análises de Desempenho Lumínico, são normalmente escolhidas as diferentes tipologias dos apartamentos no $1^{\circ}$ pavimento tipo, que apresentam acesso a

\footnotetext{
${ }^{15}$ A incorporadora articula toda a concepção do empreendimento imobiliário que será construído. Na prática, é responsável por definir o case do empreendimento, ou seja, identificação de oportunidades de mercado, compra do terreno, definição dos detalhes do produto que será vendido, viabilidade da concepção e construção do imóvel e documentação jurídica das unidades imobiliárias.
} 
iluminação natural menos favorável e as coberturas privativas.

Os edifícios vizinhos apresentam a principal obstrução da abóbada celeste, fonte luminosa de iluminação natural indireta. Sendo o bairro todo planejado, com todas as projeções e volumetrias dos edifícios definidas, é possível modular todas as edificações vizinhas, mesmo as que ainda não possuem projeto e ainda não foram construídas, conforme ilustra a Figura 12. Outra obstrução que se tem mostrado importante, é a caixa de escada do próprio edifício, quando locada para fora da projeção.

Figura 12: Evolução das mudanças no pavimento tipo em função do avanço em espaço aéreo.

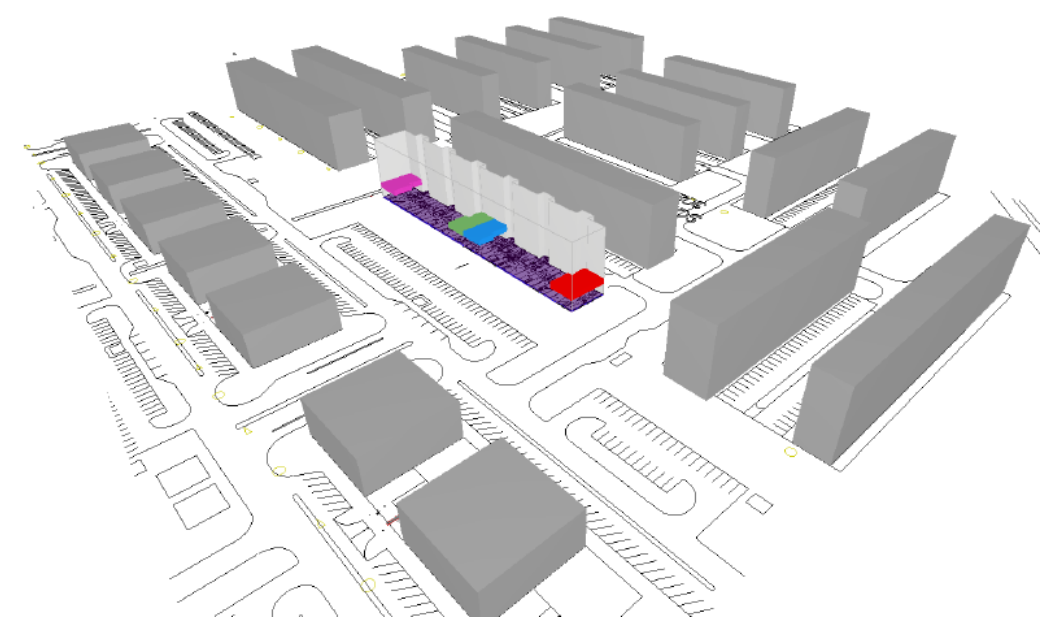

Fonte: Kos (2019) análise de desempenho lumínico para atendimento à ABNT NBR 15.575 SQNW 302 projeção C, Brasília-DF

No entanto, o principal desafio de se obter as unidades habitacionais bem iluminadas, é a largura dos edifícios, que implica em plantas profundas. Conforme exposto no item 2.1, são três tipos de volumetrias: edifícios retangulares e quadrados de 6 pavimentos acima de pilotis; e edifícios quadrados de 2 pavimentos, acima de pilotis. Os edifícios de 6 pavimentos são exclusivamente residenciais e destinados a unidades habitacionais de dois quartos ou maiores. Os edifícios quadrados de 2 pavimentos têm o uso misto, possuem unidades comerciais no térreo e mezanino e unidades habitacionais econômicas de até 2 quartos nos $1^{\circ} \mathrm{e} 2^{\circ}$ pavimentos.

Embora, em sua grande maioria, os cômodos atendam aos níveis intermediário e superior, a forma imposta pelo partido urbanístico traz desafios para o arquiteto. A dimensão da projeção somada aos avanços de 2 metros consolidados ao longo dos anos (Figuras 04 e 05) resulta em plantas com cômodos, em geral salas e cozinhas, excessivamente profundos e estreitos que configuram o maior gargalo para atender ao Desempenho Lumínico mínimo. Nos apartamentos de meio, por terem menos área de fachada, a entrada de luz é significativamente pior do que nos apartamentos de canto (Kos, 2014 a 2020). Além disso, também há maior obstrução do céu em virtude dos edifícios vizinhos, conforme demonstra a planta da superquadra (Figura 03 e 04).

Quanto à profundidade das dependências, nas projeções retangulares com partido de apartamentos vazados é possível encontrar quartos, salas e cozinhas com 7 metros de profundidade. Nas cozinhas, os desafios são ainda maiores. A solução mais usual dos arquitetos é locar a cozinha próximo a torre de circulação vertical. Assim, além da profundidade, somam-se os obstáculos das lajes técnicas, obrigatoriamente na frente das janelas, e as torres de circulação vertical para fora da projeção, que funcionam como sombreamento externo (Figuras 14 e 15). Igualmente, as varandas também funcionam como sombreamento para as salas. Desse modo, é recorrente nas aberturas dos cômodos recuados de salas e cozinhas, a especificação de vidro incolor, que possui maior transmissão de luz.

As Figura 13, 14 e 15 ilustram exemplos de configuração de apartamentos de 3 e 4 quartos de meio vazados para uma projeção retangular do Setor Noroeste. 
Figura 13: Exemplo de planta de pavimento tipo para uma projeção retangular residencial.

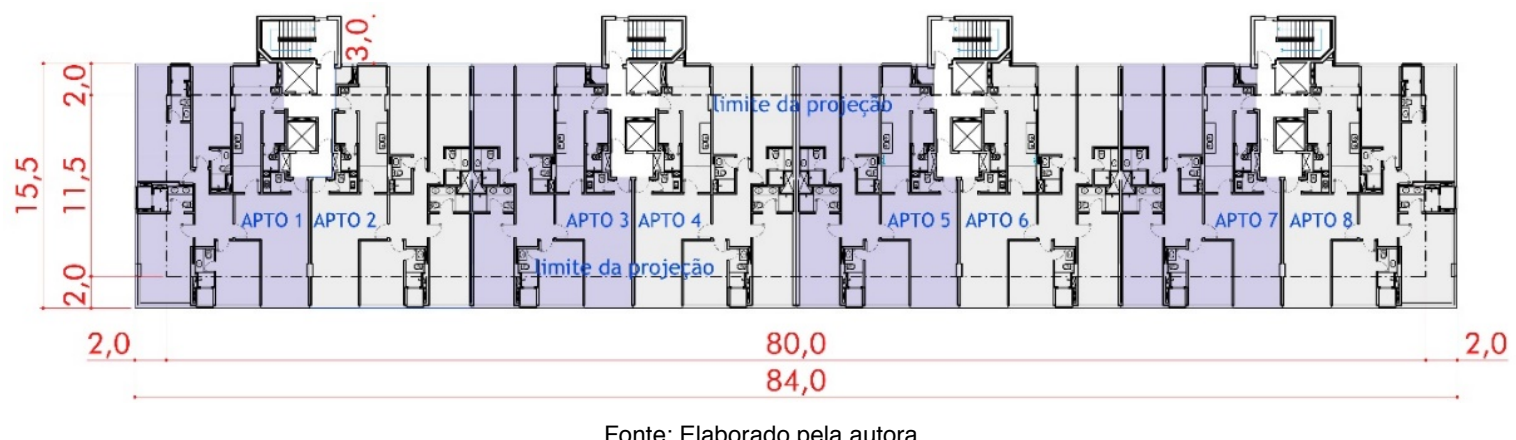

Figura 14: Exemplo de planta de apartamentos 3 quartos de meio para uma projeção retangular.

Figura 11: Desempenho lumínico da cozinha. Software ReluxPro2014, versão 1.2.0.

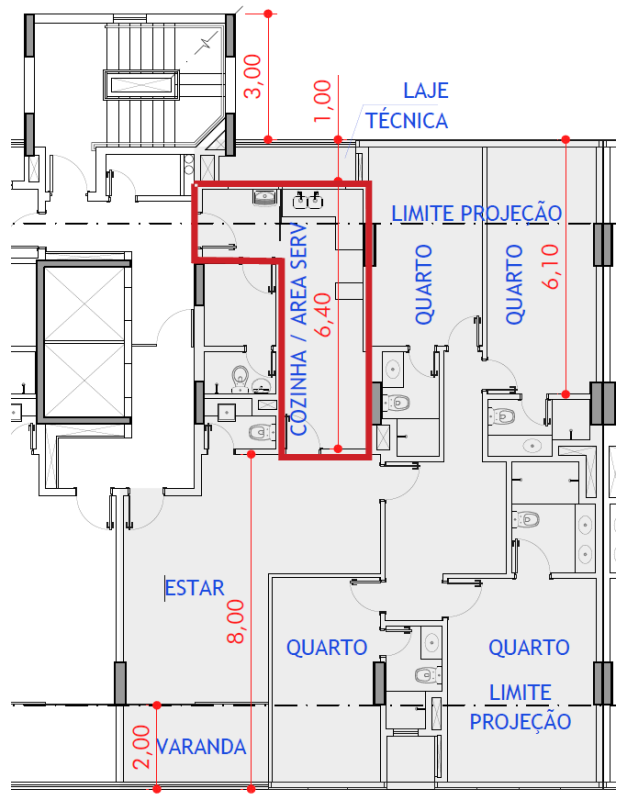

Fonte: Elaborado pela autora. SQNW 102 projeção H, Brasília-DF

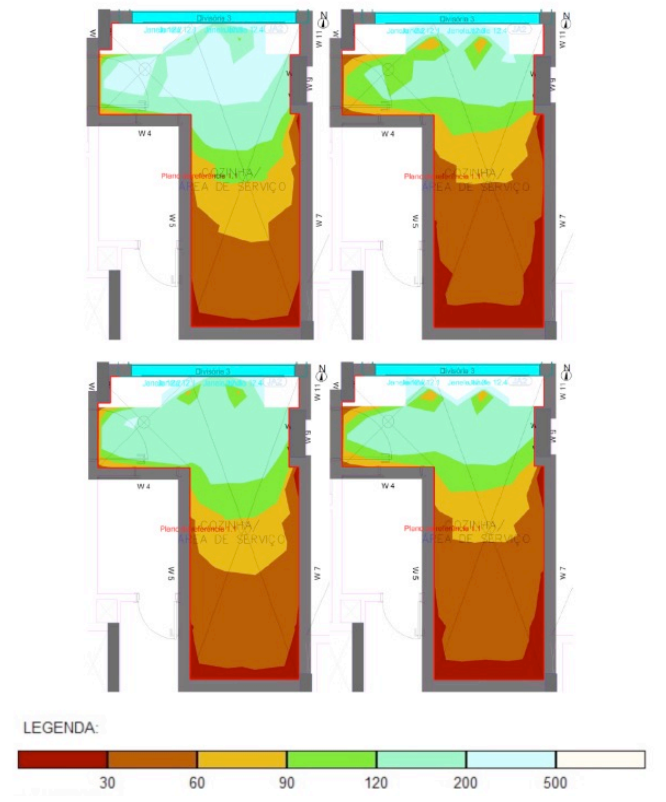

Fonte: Kos (2016) análise de desempenho lumínico para atendimento à ABNT NBR 15.575 SQNW 102 projeção $H$, Brasília-DF

Já nas projeções quadradas de 6 pavimentos, o desafio para o lumínico é ainda maior, pois se tem muito mais área útil interna e menos área de fachada, chegando a apresentar apartamentos com plantas de até 15,00 metros de profundidade (Figuras 5 e 16). Segundo Lamberts et all (2014), em edificações com vários pavimentos, normalmente, apenas a faixa até 5,0 metros da fachada pode ser totalmente iluminada com a luz natural. As áreas afastadas até 10,0 metros podem ser iluminadas parcialmente pela luz natural e as mais profundas apenas com a luz artificial.

Para os partidos arquitetônicos de projeções quadradas, o ideal seria a criação de átrio interno, porém financeiramente inviável devido à grande perda de área de venda. Os dutos de luz natural também são tecnicamente inviáveis para os apartamentos nos pavimentos mais baixos. Usualmente, para esse tipo de projeção, os projetos destinam cômodos que não exigem ventilação natural, como banheiros, closet, vestiários para o centro da projeção. Até mesmo a sala íntima é denominada como hall íntimo para se esquivar da obrigatoriedade de iluminação e ventilação.

Nas projeções quadradas de 2 pavimentos, destinadas às unidades habitacionais econômicas de 1 e 2 quartos com área máxima de $68 \mathrm{~m}^{2}$, a situação é ainda mais crítica. Para iluminação dos apartamentos locados no centro da projeção, a única solução é a criação de átrios internos (Figuras 6 e 17). Estes 
costumam ter largura mínima necessária para atendimento das unidades adjacentes ao nível mínimo de Desempenho Lumínico, visando minorar a perda de área útil privativa interna. Os apartamentos voltados para estes átrios não possuem vista externa. Para o partido de edifício de apartamentos econômicos, a projeção retangular seria mais adequada e eficiente, pois se tem muito mais área de fachada para dispor as unidades imobiliárias. Todavia, a proposta de projeto urbanismo não prevê projeções retangulares no comércio, e a lei local não permite apartamentos de 1 quarto dentro das Superquadras Noroeste.

Figura 16: Exemplo de planta de pavimento tipo para uma projeção quadrada residencial (6 pavimentos).

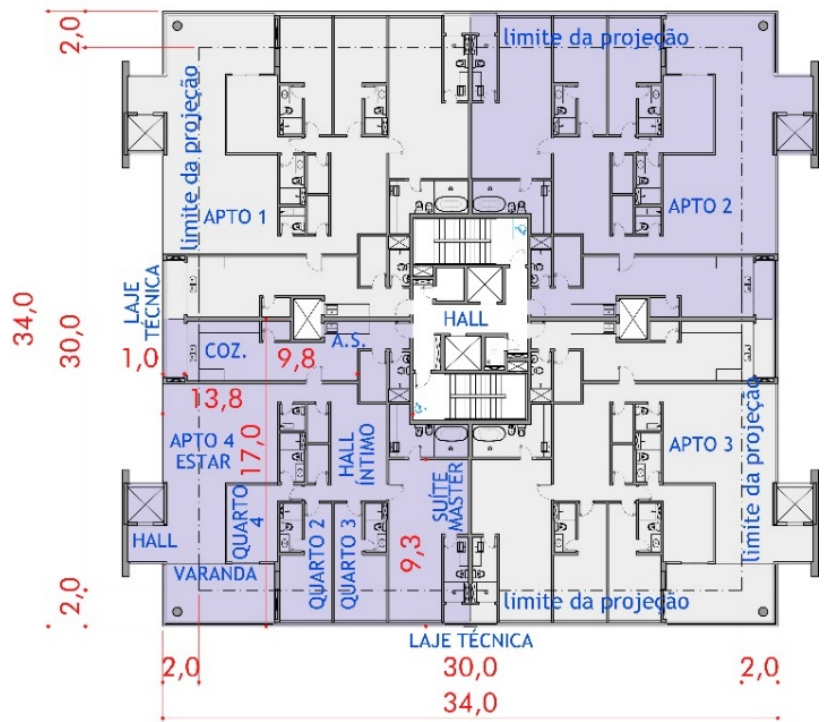

Fonte: Elaborado pela autora
Figura 17: Exemplo de planta de pavimento tipo para uma projeção quadrada mista (2 pavimentos).

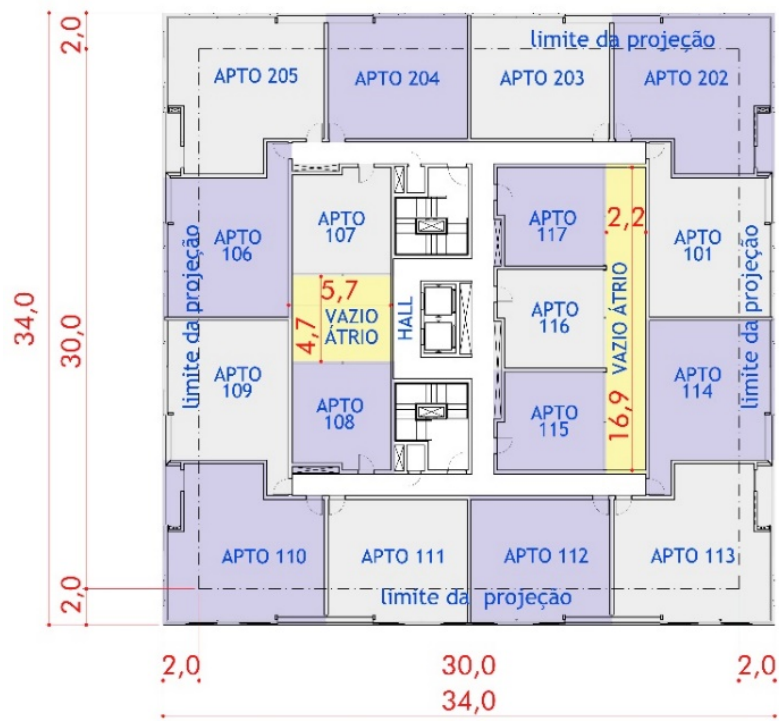

Fonte: adaptado de Vilas Boas Incorporadora, Crosara Arquitetura

Por fim, para atendimento ao Desempenho Térmico, é imperativo o uso de vidro de controle solar com fator solar baixo. Com isso, a especificação do vidro da fachada se torna mais um desafio. A maioria desses vidros possui transmissão luminosa abaixo de $40 \%$, enquanto a transmissão luminosa de vidro incolor gira em torno de $88 \%$. Para dificultar, quanto maior a transmissão luminosa em relação ao fator solar, mais caro é o vidro. Uma das soluções seria especificar vidros mais escuros, com fator solar mais baixo nos apartamentos de canto e vidros mais claros nos apartamentos de meio, a depender da orientação solar. Ainda não há construções que contemplem essa premissa, muito provável por receio estético ou conservadorismo dos arquitetos e incorporadoras.

No Noroeste, a maioria dos blocos residenciais analisados e adequados pós-análise atendem ao Desempenho Lumínico em conformidade com a NBR15.575. As maiores dificuldades de projeto frente à legislação são a profundidade dos apartamentos, em virtude dos avanços em espaço aéreo, e o sombreamento das caixas de escada. Importante notar que enquanto esse sombreamento pode ser avaliado e reposicionado conforme o partido, a profundidade do apartamento e orientação do terreno são limitantes imutáveis. Apesar de os blocos do Noroeste apresentarem $50 \%$ ou mais de fachada em vidro, isso não implica garantia de boa iluminação natural para todos os cômodos das unidades.

Conforme a norma NBR ISO/CIE 8.995-1 (ABNT, 2013b), que estabelece iluminâncias mínimas para ambientes de trabalho, as atividades de ler, de escrever e de teclar, por exemplo, demandam iluminância de 500 lux na área de tarefa e de 300 lux no entorno imediato. Da mesma forma, atividade profissional de cozinhar, exige 500lux na área da tarefa e de 300 lux no entorno imediato.

As atividades de ler, escrever, teclar e cozinhar comumente acontecem em residências, ainda mais agora, durante a pandemia da Covid-19. A comparação de iluminâncias estabelecidas na NBR 15.575 com as da NBR 8.995, mostra incoerência entre os valores. Pela NBR 15.575, um quarto, uma sala ou 
uma cozinha atende ao nível superior de iluminação natural, quando apresenta iluminância de 120 lux ou maior, no centro do ambiente, nas quatro simulações. Já para a NBR 8.995, são necessários, pelo menos, 300 lux no entorno das atividades como cozinhar, ler, escrever e usar computador. Assim, compreende-se que as iluminâncias exigidas pela Norma de Desempenho, para atendimento aos níveis intermediário e superior, são muito baixas e longe de garantir conforto luminoso.

\section{Conclusão}

Em um bom projeto de arquitetura, a forma e a orientação são pensadas em função do clima e da radiação solar. No entanto, no bairro Noroeste, a implantação, a orientação e a volumetria das edificações são impostas pelo projeto de urbanismo. Já a legislação traz limitantes quanto ao material usado na fachada, exigindo transparência visual em detrimento das faces opacas nos avanços em espaço aéreo, trazendo a raiz da questão do Desempenho Térmico. Além disso, a normativa autoriza grande aumento de área com os avanços aéreos de 2 metros, o que beneficia as incorporadoras e acarreta apartamentos mais profundos, cerne dos desafios encontrados do Desempenho Lumínico para os projetos de arquitetura.

Conforme exposto, os limitantes presentes nas normas urbanísticas e edilícias do Noroeste, somados à demanda do mercado imobiliário por mais área privativa vendável, legitimam a lógica capitalista por menor custo e maior lucro, engessam a volumetria dos edifícios, a configuração dos apartamentos e a composição plástica da envoltória. Esse contexto compromete, principalmente, o futuro usuário e configura um grande desafio para a prática de projeto do arquiteto para um edifício residencial de projeção no Plano Piloto.

Cabe para o futuro, portanto, a discussão oportuna quanto ao papel do arquiteto no momento em que a arquitetura, enquanto edificação, transforma-se em um negócio empresarial imobiliário em detrimento das necessidades do usuário. A busca por uma arquitetura de qualidade, cujos objetivos da construção apresentem o equilíbrio entre a modelagem financeira, a estética da fachada e a satisfação do usuário. Cabe, ainda, levantar a importância da conscientização do usuário em exigir construções de qualidade, ao ponto de levar as certificações que avaliam o conforto, a eficiência energética e a sustentabilidade ambiental ao patamar de apelo mercadológico.

\section{Referências Bibliográficas}

Associação Brasileira de Normas Técnicas (ABNT) NBR 15.575: Edificações Habitacionais - Desempenho, Brasil, 2013a.

NBR 8.995-1: Iluminação de Ambientes de Trabalho, Brasil, 2013 b.

BRAGA, Darja Kos. Arquitetura residencial das superquadras do Plano Piloto de Brasília: aspectos de conforto térmico. Dissertação de Mestrado - Faculdade de Arquitetura e Urbanismo, Universidade de Brasília, 2005.

KOS, Darja. Relatórios de Análises de Desempenho Lumínico (NBR15.575/2013). Ambiente Eficiente Consultoria, Brasília - 2014 a 2020

BRASILIA. Lei Complementar $n^{\circ} 755$, de 28 de janeiro de 2008. Define critérios para ocupação de área pública no Distrito Federal mediante concessão de direito real de uso e concessão de uso para as utilizações que especifica. Brasília, 2008

MDE 40_07. Memorial Descritivo Setor Habitações Coletivas Noroeste Superquadras 107 a 111, 307 a 311, Quadras 507 a 511, 707 a 711, CLNW 06/07, 08/09, 10/11, EQN 08/09, 10/11 e CRENW. Brasília, 2007.

NGB 019/09. Norma de Edificação, Uso e Gabarito SQNW - Superquadra Noroeste - Quadras 
107 a 111, 307 a 311 (Habitação Coletiva). Brasília, 2009.

NGB 115/10. Norma de Edificação, Uso e Gabarito SQNW - Superquadra Noroeste - Quadras 102 a 106, 302 a 306 (Habitação Coletiva). Brasília, 2012.

COSTA, Lúcio. Brasília Revisitada. In: Anexo I do Decreto $\mathrm{n}^{\circ}$ 10.829/1987 - GDF e da Portaria $\mathrm{n}^{\circ}$ 314/1992 - Iphan, 1987.

Relatório do Plano Piloto de Brasília. Brasília: Codeplan e DePHA- GDF, 1991.

FISCHER, S.; Leitão, F. B. Os blocos residenciais das superquadras do Plano Piloto de Brasília. In LEITÃO, Francisco et al. Brasília 1960-2010: passado, presente e futuro. Brasília: Secretaria de Estado de Desenvolvimento Urbano e Meio Ambiente, 2009. p.255-269

LAMBERTS, R.; et al. Eficiência energética na arquitetura. $3^{\text {a }}$ Edição. Eletrobras/Procel, 2014.

LAMBERTS, R.; et al. Desempenho Térmico de Edificações. $7^{a}$ Edição. Laboratório de Eficiência Energética em Edificações, Departamento de Engenharia Civil, Universidade de Santa Catarina, Florianópolis, 2016.

MACHADO, M. P. Superquadra: pensamento e prática urbanística. Dissertação de Mestrado Faculdade de Arquitetura e Urbanismo, Universidade de Brasília. UnB. 2007.

NICOLETTI, Ana Maria Abrahão. Relatórios de Análises de Desempenho Térmico (NBR15.575/2013). Ambiente Eficiente Consultoria, Brasília - 2014 a 2020.

SILVA, C.F., 2013. O conforto térmico de cavidades urbanas: contexto climático do Distrito Federal. Tese de Doutorado - Faculdade de Arquitetura e Urbanismo, Universidade de Brasília. UnB2013.

SORGATO, M. J.; et al. Análise do procedimento de simulação da NBR 15575 para avaliação do desempenho térmico de edificações residenciais. Ambiente Construído, Porto Alegre, v. 14, n. 4, p. 83-101, out./dez. 2014. 


\section{Patrícia von Glehn}

Arquiteta e Urbanista pela Universidade de Brasília (2008). Especialização em Reabilitação Ambiental Sustentável Arquitetônica e Urbanística pela FAU-UnB (2020). Sócia da Reis Arquitetura S/S, atuando como diretora de projetos de médio e grande porte. Tem experiência na área de Arquitetura e Urbanismo com ênfase em projetos prediais de grande porte para o mercado imobiliário, Planejamento e Desenho Urbano e modelagens PPPs. Atuou como arquiteta coordenadora nos escritórios MKZ Arquitetura (2010-2017) e PAVTO Arquitetos Associados (2017-2019). E fez parte da equipe multidisciplinar da Tecnhum Consultoria (2008-2010) atuando na área de planejamento urbano e legislação urbanística e edilícia colaborando com diversos planos diretores municipais pelo Brasil.

Contribuição de autoria: fundamentação teórico-conceitual e problematização; pesquisa de dados e análise estatística; elaboração de figuras e tabelas; Fotos; elaboração e redação do texto; seleção das referências bibliográficas; revisão do texto.

\section{Darja Kos}

Natural de Ljubljana - Eslovênia. Mora no Brasil desde 1994. Arquiteta pela Faculdade de Arquitetura e Urbanismo da Universidade Presbitariana Mackenzie de São Paulo (1999). Mestre em Arquitetura e Urbanismo pela Universidade de Brasília, na área de conforto ambiental (2005). Possui MBA em Construções Sustentáveis pela Universidade Cidade de São Paulo (UNICID). Desde 2007 atua como professora do Curso de Especialização em Reabilitação Sustentável Arquitetônica e Urbanística (Reabilita) ministrado pela FAU/UnB. Sócia-diretora da empresa Ambiente Eficiente Consultoria, desde 2011. Consultora capacitada pela Fundação Vanzolini no Processo AQUA-HQE (Haute Qualité Environnementale) e pelo LACAM/FAU/UnB no processo de etiquetagem de edifícios PROCEL/Inmetro. Credenciada LEED GA (Green Associate) pelo Green Building Council Institute (GBCl). Consultora GBC Brasil Casa pelo Green Building Council Brasil. Profissional HBC PRO pelo Healthy Building Certificate (HBC). Atua sobretudo nas áreas de eficiência energética, iluminação natural, conforto térmico e sustentabilidade nas edificações.

Contribuição de autoria: fundamentação teórico-conceitual e problematização, elaboração e redação do texto, revisão do texto.

Como citar: GLEHN, Patrícia von; KOS, Darja. Reflexão sobre o impacto dos códigos edilícios no desempenho térmico e lumínico de edifícios residenciais do bairro Noroeste, Brasília-DF. Revista Paranoá.n. 30, Edição Temática: Olhares de Reabilitação Sustentável 3. DOI 10.18830/issn.16790944.n30.2021.02

Editoras responsáveis: Caio Frederico e Silva e Daniel Richard Sant’Anna. 